\title{
How Intellectual Stimulation Effects Knowledge Sharing, Innovation and Firm Performance
}

\author{
Fauji and Mira Maulani Utami
}

\begin{abstract}
The purpose of this paper that determine whether the intellectual stimulation can influence innovation which is mediated by knowledge sharing, and whether innovation can improve a firm's performance. The model tested on the 56 owners of small and medium enterprises (SMEs) in Tegal, Indonesia. Utilizing purposive sampling technique, with the follwing criteria, company has a workforce 5 to 100 people, engaged in the metal and machinery industry, not including to foreign-owned companies. Software analysis techniques PLS (Partial Least Square) are used in this research. The final results indicate that there are positive effects on intellectual stimulation, experiential sharing and explicit knowledge sharing; explicit knowledge sharing has a positive effect on product innovation and product innovation has a positive effect on business performance. While experiential sharing has a positive effect on product innovation, it is not significant, so the hypothesis is rejected. This study has important managerial implications, the psychological barriers that prevent employees sharing knowldge and experience can be enhanced through intellectual stimulation of transformational leaders, in this case the leader to be a role model that can be replicated and duplicated by subordinates or employees.
\end{abstract}

Index Terms - Intellectual stimulation, knowledge sharing, innovation, firm performance.

\section{INTRODUCTION}

Relationship of transformational leadership and innovation has been studied intensively in recent years. Some previous research has shown the influence of transformational leadership on innovation. Transformational leadership is closely linked to the behaviour of employees in the implementation of innovation [1]. Transformational leaders have a good effect on creativity on employees and the organization [2]. Transformational leadership improve employee empowerment and organizational climate which supports innovation [3]. However, not many studies that examine the effect of intellectual stimulation, as one dimension of transformational leadership, are related to the innovation.

Small and medium scale enterprises (SMEs) in Indonesia are the backbone of the national economy. Its existence has been shown to drive the wheels of the economy and reduce the number of unemployment. Statistics in 2010 showed that there are 3.8 million SMEs which are spread throughout Indonesia and absorb approximately 8.75 million workers, and contributes for about $32 \%$ of Gross Domestic Product (GDP), which is export indutry value

Manuscript received April 9, 2013; revised June 9, 2013

Fauji and Mira Maulani Utami are with Sultan Ageng Tirtayasa University, Serang, Banten Indonesia (e-mail: fauzi.sanusi@yahoo.com, mira.maulani@yahoo.com). arround USD 13.5 bilion.

Although this sector has a variety of limitations, in fact they are able to compete with other companies. Even when economic conditions are getting worse and many large companies are threatened with bankruptcy, the sector is still able to survive and even to grow. Tegal, Central Java, Indonesia is the central activity of SMEs which still survive, such as in the metal and machinery industry.

In the knowledge based-economy, having a successful leader is one of the most effective ways to manage the source of organizational knowledge and the ability in engineering knowledge [4]. The role of leadership in knowledge based management focused on implementing and creating knowledge sharing. Creating and managing the successful of knowledge [5]. Leader as an innovator, teacher and facilitator have positive influences on organizational knowledge sharing [6].

The concept developed by a resource based-view (RBV) stated that company be regarded as a ligament of heterogeneous resources distributed to most of the company and this resources will persist over the time in those company [7], [8]. Knowledge is regarded as the most significant strategies of company. The company's ability to acquire, integrate, store, distribute and apply knowledge into an enterprise capabilities, will be able to build and maintain sustainable competitive advantage of the company. The companies which has a superior knowledge, holding an ability to coordinate and combine traditional knowledge and it's capability with unique and latest way in order to give the greater value to the consumer than the competitor [9]. Competitive advantage in the future is determined by the knowledge worker as a resource owned by the company [10].

Various studies show that knowledge sharing will contribute to organizational capabilities, such as innovation which is very important factor in determining the performance of the business [11]. Knowledge sharing activities with colleagues in the company may be very difficult, but few empirical studies indicate this activity is positively associated with a decrease in production costs. The more to work on the latest development projects, improvements team performance, improve innovation capabilities and business performance, including sales growth.

Discussions about knowledge sharing are a very important activity for building competitive advantage, but it is difficult to implement. Knowledge sharing does not happen automatically; therefore team leaders have an important role to create the activity [12]. Obstacles may arise in knowledge sharing activities that are individual barriers, organizational barriers and technology barriers [13]. Corporate leaders have a very important role in encouraging 
knowledge-sharing activities. Corporate leaders as a mentors and facilitators will be able to create conducive environments to share knowledge in a company, and teach skills and experiences to their colleagues.

The successful leader is the most important factors in managing and engineering the resources of organizational knowledge [4]. Transformational leadership style will involve human interaction and encourage participation in the decision-making process that is positively related to the skills and characteristics, which are essential to the knowledge management, [14]. Transformational leadership styles encourage the knowledge creation, knowledge sharing, commitment and trust of consumers, improvement in firm performance, competence and innovation.

Both theories and business phenomenon as described above, are interested in reasearching on metals and machine SME's industry in Tegal, Central Java, Indonesia. The research aims to explore how the role of intellectual stimulation as one dimension of transformational leadership can affect the activity of knowledge sharing and innovation which finally will affect business performance.

\section{CONCEPTUAl Model AND Hypotheses}

\section{A. Transformational Leadership}

Transformational leadership is as a set of behaviours including influence idealization, inspirational motivation, individualized consideration, and intellectual stimulation that changing needs and expectations of followers to the higher level [15]. Transformational leaders have the assumption that people are basically positive that looked followers or employees as the person responsible, and have good awareness to work with and be proud of his job. Intellectual stimulation is a leader behaviour that promotes intelligence, knowledge and learning of employees, so they could be more innovative in solving their problems and finding solutions [16].

Intellectual stimulation is characteristic of transformational leaders who develop competence followers, stimulate creative thinking to generate innovative ideas, and teach how to think about a variety of things with a new alternative. Transformational leaders always encourage internal learning climate through the provision of necessary requirements. Through intellectual stimulation, followers are challenged to find new ways in doing their job. The followers are challenged with the question, whether they are in line with the goals of the organization in general [17]. Intellectual stimulation will increase the ability of subordinates to understand and solve the problems, thoughtprovoking and imaginative exercise, including changes in values and beliefs.

\section{B. Knowledge Sharing}

Knowledge Sharing is an important part of knowledge management [18]. Knowledge sharing is defined as a series of actions taken by employees in disseminating relevant information to other employees within the company [19]. Knowledge sharing is as a cultural social interaction through knowledge change activies, skill and experience of employees in all departments of organization [20]. Successful implementation of knowledge sharing depends on the attitude of employees towards knowledge sharing, and it is influenced by the intention of knowldge sharing [21]. The intention of knowldge sharing is the willingness to share knowledge[18].

Knowledge sharing consists of tacit and explicit knowledge sharing. Human experience became the basis of the activity of sharing tacit knowledge [22], [23]. Tacit knowledge sharing is the face-to-face interaction among employees to share what they know and use what they learn [24]. Tacit knowledge sharing is the employees activity in spreading knowledge, intuition, and hunches gained through past experiences [25]. Tacit knowledge is not codified, uncommunicated openly, gained by sharing experiences, observations and imitate [26].

Referring to the experiential learning theory that learning is a process where knowledge is created through the transformation of experience. Knowledge is gained by combinating and transforming the experience [27]. Someone will learn from failure than success of his/her self and the other [28]. Experiential sharing is the employee activies in sharing his success and failure experience to colleagues.

Activity of explicit knowledge sharing is a transfer of knowledge that can be institutionalized and often performed in a work environment because it can be easily obtained, codified and transferred [24]. Knowledge sharing in our researches divided into explicit knowledge sharing and experiential sharing.

\section{Intellectual Stimulation and Knowledge Sharing}

Top management support is one of important variables that can affect organizational knowledge [29]. Numerous studies have found the importance of top management support for creating a climate that supports and provides sufficient resources [30], [31]. Knowledge sharing process will be effective if supported by transformational leadership styles through intellectual stimulation [32].Transformational leadership is positively related to knowledge sharing that occurs within an organization or company [6]. Transformational leadership is built on high-quality exchange relationships between leaders and members have an important role in the development of relational identification of employees and organizational identification, which in turn will increase knowledge sharing activity [33].

Previous research has proved that intellectual stimulation has an influence on knowledge sharing activities. Intellectual stimulation, inspirational motivation and confidence among members of the organization can encourage organizational learning [34]. Intellectual stimulation challenges to become professionals in their field are having an influence on learning activity, [35]. Intellectual stimulation is positively related to team performance. Intellectual stimulation refers to the leaders challenge to developed assumptions, risk takers and to gather some follower ideas, employees must be willing to challenge the status quo, not avoid the risks and be willing to share an understanding of consumer needs and the changing environments [36]. From the description we make the following hypothesis:

- H1: Intellectual stimulation will further increase 
experiential sharing.

- H2: Intellectual stimulation will further increase explicit knowledge sharing.

\section{Knowledge Sharing and Product Inovation}

Knowledge sharing which is supported by leader intellectual stimulus will encourage new knowledge will be beneficial as a resource to solve company problems and to create more efficient production processes. Knowledge sharing among employees will enhance rapid response to customer needs at a lower cost in operation [37]. Face-toface interaction in the process of knowledge sharing is done between individuals within an organization to share experiences and knowledge so as to obtain new knowledge, learn new techniques, problem-solving skills, core competencies and starting new situation.

Previous research in the context of the relationship between innovation support effective knowledge sharing and innovation. Knowledge sharing of employees will contribute to the application of science and gain the competitive advantage [38]. Knowledge sharing with knowledge collecting dimensions have a significant effect on all types of innovation, as well as knolwedge donating that occur in groups or group level has an influence on innovation [39]. Explicit and tacit knowledge sharing affect the pace of innovation and quality innovation [24]. Knowledge donating and knowledge collecting affect the company's innovation capabilities [41]. Working experiences of employees will directly influence the higher level of team creativity and produce different products[40]. The hypothesis can be made as follows:

- H3: Experiential sharing will further enhance product innovation.

- H4: Explicit knowledge sharing will further enhance explicit product innovation.

\section{E. Product Innovation and Firm Performance Innovation}

Product Innovation and Firm Performance Innovation has been recognized as a significant motivating factor for companies to create value and sustain competitive advantage in an increasingly complex and rapidly changing external environment. Innovative companies have the ability to adapt with market change, having shorter decision chains and faster in flexibility [42]. In general, innovation can utilize the potential of existing resources, improve the efficiency and potential value, and it can be regarded as a new intangible asset for the organization.Various empirical studies show that the innovation of the company will be able to increase business performance. Product diversification mediating the relationship between export diversification and firm performance [43]. Firms with the greater innovation will be more successful in responding to cunsomers need, so it could develop new capabilities to achieve better performance or superior benefits, [44].

Innovation performance has a significant and positive impact on corporate performance [45]. Innovation of new products or services will improve corporate performance through the reduction of operating costs and quality of customer satisfaction. The faster a company introduces a new product or service into the market will improve the company performance. Innovations affect the company's financial performance which is return on assets and return on sales [46]. Product and process innovation has a strong relationship to company performance [47]. Product innovation is influenced by emotional and learning ability, which is finally having a significant impact on business performance [48]. From a review of previous reserach, it can be hypothesized as follows:

- H5: Product innovation created by company will further improve business performance.

\section{METHOD}

\section{A. Sample and Data Collection}

This study used a sample of 56 heads of small and medium-sized enterprises (SMEs) engaged in the metal and machinery industries in Tegal which has a total population of 296 SMEs. Utilizing purposive sampling technique, with the follwing criteria (1) Company has a workforce 5 to 100 people, (2) engaged in the metal and machinery industry, (3) not including to foreign-owned companies. To test the model and hypothesis utilizing Structural Equation Modelling (SEM) analysis with PLS (Partial Least Square) sofware, which use to determine whether the intellectual stimulation can influence innovation which is mediated by knowledge sharing, and whether innovation can improve a firm's performance. This research use a questioner with a likert scale (1-10), 1 for strongly disagree, and 9 for strongly agree.

\section{B. Measurement}

\section{1) Intellectual stimulation}

Based on the previous studies [49], intellectual stimulation will be measured by four indicators; Supervising the work of employees according to the standards: Directing employees to look at problems from different viewpoints; Directing employees to solve problems on different perspective; Directing to find out new ways in finishing job.

\section{2) Experiential sharing}

Based on previous studies [20], [24], [27] experiential sharing measured by 5 indicators. Sharing failures experiences in the past, gaining knowledge based on leaders experiences. Gaining knowledge based on experience of other employees. Knowledge sharing based expertise. Sharing successful experiences in the past Explicit Knowledge Sharing

\section{3) Explicit knowledge sharing}

Explicit Knowledge Sharing is a process of knowledge sharing that has been documented related to their work among employees. Utilizing four indicators [20], [24]. Knowledge sharing related to the work from the writings. Sharing knowldge from manual work with colleagues. Collecting manual work from the other. Employeess often follows development and training program.

\section{4) Innovation product}

In this study the innovation is the activity of producing new goods or services to create new markets or new customers. Innovation Product will satisfy the market and 
currect customer [47], [50]. Four indicators are used to measure this variables: Constantly creating new product which is easier to use. Constantly developing new products with different raw materials. Creating new products with different techinical and function product specifications. Constantly introducing a higher quality of new products.

\section{5) Business performance}

In previous researchs, growth is used as a proxy variable in business performance. Growth as a performance measurement may more accurate and accesible than accounting measurement and financial performance, [51]. Business performance is the company achievment which characterized by the success and efficiency of corporate behaviour [51]. Indicators used to measure this variables is combining comoany size and growth, and accounting. The indicators are; sales value, increase in profit and capital growth.

\section{RESUlt AND DisCUSSION}

Validity test of this study using convergent validity models with PLS software, this can be seen with the average variance extracted (AVE) of each construct greater than 0.5 . While the reliability test by composite reliability above 0.7 [52].

TABLE I: OUTER MODEL, DiscriminATE VALIDITY AAND COMPOSITE RELIABILITY

\begin{tabular}{clll}
\hline \hline Variable & AVE & $\begin{array}{l}\text { Composite } \\
\text { Realibility }\end{array}$ & $\begin{array}{l}\text { R } \\
\text { Square }\end{array}$ \\
\hline IS & 0.685 & 0.827 & - \\
ES & 0.785 & 0.886 & 0.923 \\
EK & 0.810 & 0.900 & 0.917 \\
S & & & \\
IP & 0.816 & 0.903 & 0.945 \\
BP & 0.875 & 0.935 & 0.951 \\
\hline \hline
\end{tabular}

Table I, indicates that the value of AVE each constructs: Intellectual Stimulation (IS), Experiential Sharing (ES), Explicit Knowledge Sharing (EKS), Product Innovation (IP), Firm Perfomance (BP). The AVE value of each construct above 0.5 , it shows that the indicators of each construct and questionnaire can be used in explaining the variables.

\begin{tabular}{cccccc}
\multicolumn{5}{c}{ TABLE II: RESULT FROM INNER WEIGHT } \\
\hline & $\begin{array}{c}\text { Original } \\
\text { Sample } \\
\text { Estimate }\end{array}$ & $\begin{array}{c}\text { Mean of } \\
\text { sub } \\
\text { samples }\end{array}$ & $\begin{array}{c}\text { Standard } \\
\text { deviation }\end{array}$ & $\begin{array}{c}\text { T- } \\
\text { Statistic }\end{array}$ & Decision \\
\hline IS $\rightarrow$ ES & 0.45 & 0.415 & 0.259 & 1.737 & Accepted \\
IS $\rightarrow$ EKS & 0.489 & 0.417 & 0.291 & 1.688 & Accepted \\
ES $\rightarrow$ IP & 0.242 & 0.15 & 0.188 & 1.287 & Rejected \\
EKS $\rightarrow$ IP & 0.759 & 0.849 & 0.186 & 4.081 & Accepted \\
IP $\rightarrow$ BP & 0.981 & 0.983 & 0.005 & 19.525 & Accepted \\
\hline \hline
\end{tabular}

From Table I, each construct or latent variables has composite reliability which is above 0.7 . Indicates that the internal consistency of the exogenous variables (IS) and endogenous variables (ES, EKS, IP and BP) have good reliability.Parameter estimation has been shown from the significant value of the relationship of each variable in this study, the limit acceptance and rejection of the hypothesis is comparison of $\mathrm{T}$ Statistic and $\mathrm{T}$ count (1.684). Another interpretation of $\mathrm{T}$ statistic $<\mathrm{T}$ table are the hypothesis is rejected, while if the value of $\mathrm{T}$ statistics $>$ of the $\mathrm{T}$ table, the hypothesis is accepted.

Based on Table II it can be explained as follows: the relationship between IS to ES positive with a value of 0.450 and significant at the 0.05 level of sig (1.737> 1.684), hypothesis 1 is accepted. IS to EKS positive relationship with the value of 0.489 and significant at the 0.05 level of sig $(1.688>1.684)$, hypothesis 2 is accepted. ES to a positive relationship with the value of IP 0.242 and significant at the 0.05 level of $\operatorname{sig}(1.287<1.684)$, hypothesis 3 is rejected. IP EKS positive relationship to the value of 0.759 and significant at the 0.05 level of sig (4.081> 1.684), hypothesis 4 is accepted. IP to a positive relationship with the value of BP 0.981 and significant at the 0.05 level of sig $(19.525>1.684)$, hypothesis 5 is accepted.

\section{CONCLUSION}

This study has shown the importance of support from top management to ensure the willingness of knowledge sharing activities with colleagues. Intellectual stimulation as one dimention of transformational leadership has a positive and significant impact on experiential sharing and explicit knowldge sharing. Results of this study support previous research conducted by Coad and Berry, (1998), Chen and Barnes, (2007). Other findings have shown that explicit knowledge sharing, which is conducted by employee has a positive and significant effect on product innovation. This shows that the sharing of knowledge through various reports and documents related to the job. Can increase employees creativity including creating new products. While the sharing of experience among employees has no effect significantly on product innovation, this shows that there is no openness among employees to share their past experiences with their peers. Other findings show that product innovation on business performances. These findings support previous research conducted by Sadigoklu \& Zehir, (2010), Kostopoulos et al., (2011) and Murat and Baki. This study has important managerial implications The psychological barriers that prevent employees sharing knowldge and experience can be enhanced through intellectual stimulation of transformational leaders, in this case the leader to be a role model that can be replicated and duplicated by subordinates or employees. Intellectual stimulation that can implement by the Focus Grop Discussion conducted within the organizational continually. Limitations of this study involve a small number of the sample, because the time of the study was conducted only three months. A subsequent study should be conducted longitudinally larger sampling and longer study time and improve coverage of multiple learning culture variables and availability of information technology

\section{REFERENCES}

[1] B. Michaelis, R. Stegmaier, and K. Sonntag, "Shedding light on followers' innovation implementation behavior," Journal of Management Psychology, vol. 25, no. 4, 408-429, 2010.

[2] G. Lale and İ. Arzu, "Transformational leadership, creativity, and organizational innovation," Journal of Business Research, vol. 62, pp. 461-473, 2009.

[3] D. I. Jung, C. Chow, and A. Wu, "The role of transformational leadership in enhancing organizational innovation: hypotheses and 
some preliminary findings," Leadership Quarterly, vol. 14, pp. 52544, 2003.

[4] C. W. Holsapple and K. D. Joshi, "An investigation of factors that influence the management of knowledge in organizations," The Journal of Strategic Information Systems, vol. 9, no. 2/3, pp. 235-61, 2000.

[5] K. Nonaka and Rechsteiner, "Leadership in organizational knowledge creation: a review and framework," Journal of Management Studies, 2011.

[6] J.-T. Yang, "Knowledge sharing: investigating appropriate leadership roles and collaborative culture," Tourism Management, vol. 28, pp. 530-543, 2007.

[7] R. Amit and P. J. H. Schoemaker, "Strategic assets and organizational rent," Strategic Management Journal, vol. 14, 1993.

[8] B. Wernerfelt, "A resource-based view of the firm," Strategic Management Journal, vol. 5, 1984

[9] M. H. Zack, "Developing a knowledge strategy," California Management Review, vol. 41, no. 3, pp. 125-145, 1999.

[10] P. F. Drucker, "Managing for the future: the 1990's and beyond," New York: 826 Truman Talley Books/Plume, 1993.

[11] B. Kogut and U. Zander, "What do firms do? Coordination, identity and learning," Organizational Science, vol. 7, pp. 502-18, 1996.

[12] A. Srivastava, K. Bartol, and E. A. Locke, "Empowering leadership in management teams: effects on knowledge sharing, efficacy, andknowledge sharing, efficacy, and performance," Academy of Management Journal, vol. 49, pp. 1239-51, 2006.

[13] R. Andreas, "Three dozen knowledge sharing barriers managers must consider," Journal of Knowledge. Management, vol. 9, no. 3, pp. 1835, 2005.

[14] J. D. Politis, "The relationship of various leadership styles to knowledge management," Leadership \& Organization Development Journal, vol. 22, no. 8, pp. 354-364, 2001.

[15] B. M. Bass and B. J. Avolio, "Improving organizational effectiveness through transformational leadership," Thousand Oaks, CA: Sage, 1994.

[16] Morales, Fernando Matı'as-Reche, and Torres, "Influence of transformational leadership on organizational innovation and performance depending on the level of organizational learning in the pharmaceutical sector," Journal of Organizational Change Management, vol. 21, no. 2, pp. 188-212, 2008.

[17] Nielsen and K. Daniels, "Does shared and differentiated transformational leadership predict followers' working conditions and well-being," The leadership Quarterly, 2011.

[18] G. W. Bock and Y.-G. Kim, "Breaking the myths of rewards: An exploratory study of attitudes about knowledge sharing. Information Resources," Management Journal, vol. 15, no. 2, pp. 14-21, 2002.

[19] K. Bartol and A. Srivastava, "Encouraging knowledge sharing: The role of organisational rewards," Journal of Leadership and Organisation Studies, vol. 9, no. 1, pp. 64-76, 2002.

[20] H. F. Lin, "Knowledge sharing and firm innovation capability: an empirical study," International Journal of Manpower, vol. 28, no. 3/4, pp. 315-332, 2007.

[21] M. Gagne, "A model of knowledge-sharing motivation," Human Resource Management, vol. 48, pp. 571-589, 2009.

[22] I. Nonaka and H. Takeuchi, The knowledge-creating company: How Japanese companies create the dynamic of innovation, New York, NY: Oxford University Press, 1995.

[23] M. Polanyi, Human knowledge, Chicago: The University of Chicago Press, 1966.

[24] Z. Wang and N. Wang, "Knowledge sharing, innovation and firm performance," Expert Systems with Applications, vol. 39, pp. 88998908, 2012.

[25] M. L. Endres, S. P. Endres, S. K. Chowdhury, and I. Alam, "Tacit Knowledge. Sharing, Self-Efficacy Theory, and Application to the Open Source Community," Journal of Knowledge Management, vol. 11, no. 3, pp. 92-103, 2007.

[26] K. Rifat and F. Bulutlar, "The influence of knowledge sharing on innovation," European Business Review, vol. 22, no. 3, pp. 306-317, 2010.

[27] D. A. Kolb, Experiential Learning: Experience as the source of learning and development, Englewood Cliffs, N. J.: Prentice-Hall, 1984.

[28] K. C. Diwas, B. R. Staats, and F. Gino, "Learning from my success and from others' failure: evidence from minimally invasive cardiac surgery," Working paper, Harvard Business School, 2012.

[29] C. E. Connelly and E. K. Kelloway, "Predictors of employees' perceptions of knowledge sharing culture," Leadership \& Organization Development Journal, vol. 24, no. 5, pp. 294-301, 2003.
[30] H. F. Lin and G. G. Lee, "Effects of socio-technical factors on organizational intention to encourage knowledge sharing," Management Decision, vol. 44, no. 1, pp. 74-88, 2006.

[31] C. M. MacNeil, "Exploring the supervisor role as a facilitator of knowledge sharing in teams," Journal of European Industrial Training, vol. 28, no. 1, pp. 93-102, 2004.

[32] L. Y. Chen and F. B. Barnes, "Relationship between leadership behaviors and knowledge sharing in professional service firms engaged in strategic alliances," The Journal Applied Management and Entrepreneurship, vol. 11, no. 2, pp. 51-69, Industrial Training, vol. 28, no. 1, pp. 93-102, 2007.

[33] A. Carmeli, L. Atwater, and A. Levi, "How leadership enhances employees' knowledge sharing: the intervening roles of relational and organizational identification," Journal Technol Transf, vol. 36, pp. $257-274,2010$.

[34] A. F. Coad and A. J. Berry, "Transformational leadership and learning orientation," Leadership \& Organization Development Journal, vol. 19/3, pp. 164-172, 1999.

[35] F. Geijsel, R. van den Berg, and P. Sleegers, "The innovative capacity of schools in primary education: A second qualitative study," International Journal of Qualitative Studies in Education, vol. 12, no. 2, pp. 175-191, 1999.

[36] P. Lee, T. Cheng, A. Yeung, and K. Lai, "An empirical study of transformational leadership, team performance and service quality in retail banks," Omega, vol. 39, pp. 690-701, 2011.

[37] P. J. Sher and V. C. Lee, "Information technology as a facilitator for enhancing dynamic capabilities through knowledge management," Information \& Management, vol. 41, pp. 933-945, 2004.

[38] S. Wang and R. A. Noe, "Knowledge sharing: A review and directions for future research," Human Resource Management Review, vol. 20, pp. 115-131, 2010.

[39] K. Rifat and F. Bulutlar, "The influence of knowledge sharing on innovation," European Business Review, vol. 22, no, 3, pp. 306-317, 2010.

[40] H. F. Lin, "Knowledge sharing and firm innovation capability: an empirical study," International Journal of. Manpower, vol. 28, no. 3/4, pp. 315-332, 2007.

[41] F. Gino, L. Argote, M.-S. Ella, and G. Todorova, "First, get your feet wet: The effects of learning from direct and indirect experience on team creativity," Organizational Behavior and Human Decision Processes, vol. 111, pp. 102-115, 2010.

[42] V. J. G. Morales, F. J. L. Montes, and A. J. V. Jover, "Influence of personal mastery on organizational performance through organizational learning and innovation in large firms and SMEs," Technovation, vol. 27, no. 9, pp. 547-568, 2007.

[43] M. A. Hitt, R. E. Hoskisson, and H. Kim, "International diversification: effects on innovation and firm performance in product-diversified firms," Academy of Management Journal, vol. 40, pp. 767-798, 1997.

[44] R. J. Calantone, S. T. Cavusgil, and Y. S. Zhao, "Learning orientation, firm innovation capability, and firm performance," Industrial Marketing Management, vol. 31, pp. 515-524, 2002.

[45] E. Sadikoglu and C. Zehir, "Investigating the effects of innovation and employee performance on the relationship between total quality management practices and firm performance: An empirical study of Turkish firms," International Journal of Production Economics, vol. 127, pp. 13-26/985, 2010.

[46] K. Kostopoulos, A. Papalexandris, M. Papachroni, and G. Ioannou, "Absorptive capacity, innovation, and financial performance," Journal of Business Research, vol. 64, pp. 1335-1343, 2011.

[47] M. Ilker and B. Birdogan, "Antecedents and performance impacts of product versus process innovation," European Journal of Innovation Management, vol. 14, no. 2, 2011.

[48] A. E. Akgu"n, H. Keskin, J. C. Byrne, and S. Aren, "Emotional and learning capability and their impact on product innovativeness and firm performance," Technovation, vol. 27, no.9, pp. 501-513, 2007.

[49] L. Mark, Y. M. Lim, T. H. Lee, and C. L. Tam, "Transformational leadership and job-related learning," Management Research Review, vol. 35, no. 3/4, pp. 192-205, 2012.

[50] C. L. Wang and P. K. Ahmed, "The development and validation of the organizational innovativeness construct using confirmatory factor analysis," European Journal of Innovation Management, vol. 7, no. 4, pp. 303, 2004.

[51] J. Wiklund and D. Shepherd, "Entrepreneurial orientation and Small Business Performance: a Configurational approach," Journal of Business Venturing, vol. 20, no. 1, pp. 71- 91, 2005.

[52] G. Imam, "Model Persamaan Struktural Konsep dan Aplikasi dengan Program Amos 16.0," Badan Penerbit UNDIP, Semarang, 2008. 


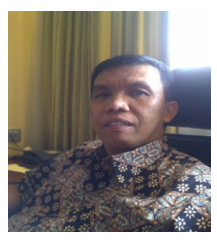

Fau Ji is the student of Economics Doctoral program, Diponegoro University, Semarang, Central Java, Indonesia. Have worked as a lecturer in The Economics Faculty of Sultan Ageng Tirtayasa University, Serang, Banten, Indonesia. Actives as a Board of Advisor of Corporate Social Responsibility in Cilegon.

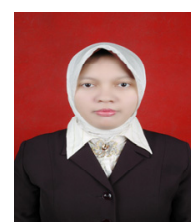

Mira have worked as a lecturer since 2010 in Economics Faculty of Sultan Ageng Tirtayasa University, Serang, Banten, Indonesia. Graduated from Magister Management of Diponegoro University in 2009, who got the best cumlaude predicate. Actives in International Social Organization (Rotaract Club of Jakarta Gambir). 